\title{
Assessing Board Members In The Nonprofit Organizational Arena: Increased Board Responsibilities Dictated By Sarbanes Oxley
}

Gregory P. Trudeau, (E-mail: gtrudeau@uwsuper.edu), University of Wisconsin-Superior

\begin{abstract}
Numerous corporate scandals of the 1990's and 2000's, coupled with public accounting firms generating high non-audit fees, eroded the publics' confidence in the concept public accounting independence. These scandals and the erosion of confidence in the auditor's independence resulted in Congress passing the Sarbanes-Oxley Act in 2002. While Sarbanes-Oxley applies mainly to publicly traded companies, proactive, progressive nonprofit organizations will also reap the benefits of Sarbanes-Oxley. In fact, Board Source (2003) indicates, "Indeed, some state attorney generals are already proposing that elements of the Sarbanes-Oxley Act be applied to nonprofit organizations." According to this author, whether this law eventually extends to the nonprofit arena or not, an increase in responsibility of board members of nonprofit organizations is inevitable. Due to the increased responsibilities board members assume, Boards would be well advised to increase their self assessment process. This paper will look at assessing the Board of Directors in light of the new responsibilities Board Members assume in conjunction with the increased responsibilities resulting from the Sarbanes-Oxley Act.
\end{abstract}

\section{SARBANES OXLEY}

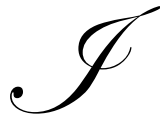

$\mathrm{n}$ the 1980's the scandals consisting of junk bonds, insider trading and misleading derivative instruments were prevalent. Leveraged buy-outs and the savings and loans debacle coupled with the stock market crash of the late 1980's brought the scandals of the 1990's (Guerra). In the early 2000's numerous companies were managing earnings through weak accounting rules. “...Enron and Krispy Kreme reportedly used off balance sheet financing to obscure long-term debt, Global Crossing swapped underwater cable rights to enhance revenue, and IBM netted the gain on an asset sale against overhead expenses (Ricchiute)." In addition to these corporate scandals, the public confidence in auditor's independence was severely damaged. This damage was caused by the publicity brought to the fact that non-audit service fees compromise an auditor's independence. The Wall Street Journal (Weil and Tannenbaum) reported that in a study of 307 of the Standard and Poor's 500 companies that made disclosures, all reported paying their auditors a non-audit fee. In fact, these non-audit fees amounted to $\$ 2.65$ billion while the audit fees amounted to $\$ 909$ million. In other words, the non-audit fees were three times the audit fees.

At that time, the bankruptcy of Enron in which management admitted to increasing earnings by approximately $\$ 600$ million, was the largest bankruptcy with assets of $\$ 62$ billion. However, less than one year later, WorldCom filed for bankruptcy with assets of $\$ 100$ billion. WorldCom subsequently was found to have been involved in massive fraud, contributing to its eventual bankruptcy. Interestingly as a side note, Arthur Anderson, one of the Big Five accounting firms at that time, audited both of these corporations. Arthur Anderson eventually ceased to exist when it was found guilty of obstruction of justice in its dealings with Enron, (Arens, Elder, \& Beasley, 2004, p.2).

The public's concern regarding the auditor's lack of independence brought on by the high non-audit fees coupled with the corporate scandals of the 1990's and 2000's prompted the SEC to conduct hearings. These hearings resulted in Congress passing the Sarbanes-Oxley Act in 2002. This act established the Public Company Accounting Oversight Board. 
According to W.H. Donaldson (2003), SEC Chairman, this act is the "most important securities legislation since the original federal securities laws of the 1930's," and will impact a "dramatic change across the corporate landscape to reestablish investor confidence in the integrity of corporate disclosures and financial reporting."

Although Sarbanes-Oxley applies mainly to publicly traded companies, it does specifically broaden the board members' role in overseeing financial transactions and auditing procedures. Despite the application toward publicly traded companies, this author believes nonprofits probably will become subject to this act or another similar act which will be drafted and applicable explicitly for the nonprofit sector. In fact, BoardSource (2003) indicates, "Indeed, some state attorney generals are already proposing that elements of the Sarbanes-Oxley Act be applied to nonprofit organizations." Further this author believes it would appear logical that if publicly traded companies hold their board members to a higher level of responsibility, the nonprofit organizations must follow suit, or risk being viewed as having a substandard quality of organizational governance. Robert Prentice (2005) also concludes that section 301 of Sarbanes-Oxley was written for publicly traded companies but is "...quickly becoming best practices for other companies, including nonprofits."

Judy Cooper, the Credit Unions National Association's (CUNA) Senior Vice President and Associate General Counsel, in the November, 2004 edition of Credit Union Magazine recognized that one outcome of the regulation is the increased recognition by all companies of the need for good corporate governance, along with the evolution of governance best practices. The National Credit Union Administration, in a letter to Federal Credit Unions, recommended consideration of the provisions of Sarbanes-Oxley as an example of best practices.

\section{WHY ASSESS A BOARD}

Section 404 of Sarbanes-Oxley requires management to assess a company's internal control. The issue of assessing internal control is not new and in fact was the thrust of the Treadway Commission formed in 1985. The result of the National Commission on Fraudulent Financial Reporting was the Committee of Sponsoring Organizations or COSO. COSO created a conceptual framework providing subjective concepts of effective internal control. This framework includes assessing risk and assessing the control environment. In fact, the control environment is viewed as the foundation for the entire organization's internal control and for the other components of internal control as outlined by COSO (Deloitte \& Touche, 2004). This control environment starts with the board and is carried down through the entire organization. This implies boards and board members need to be assessed regarding the fulfillment of their fiduciary responsibilities or the control environment is substantially weakened.

The egregious failures of assurance and oversight in Enron, WorldCom, and other corporations have initiated the repetitive question, "Where was the board?" Further the expectations of boards has risen since the public, legislators, and the courts are raising the bar in their interpretation of "good faith" by the directors in their fulfillment of fiduciary duty of care. This expectation has been heightened by the abuse of the corporate structure coupled with the broad exposure that the board of directors is responsible for the strategic choices and the performance of a corporation (Spetzler, Arnold, \& Lang, 2005, p.1).

Assessment of board is encouraged for reasons other than as a reactionary tool to Sarbanes-Oxley. Hacker (2003) indicates a major outcome of assessment is that self-assessment can serve as a motivator to each board member. This takes place because each board member can make a renewal of their commitment to the organization and its governing function. The assessment should serve as a reminder as to what the board members are responsible for and allow reflections upon whether or not the individuals have fulfilled that obligation.

Finally, a board would not hire a CEO who lacks the appropriate credentials, experience or skills, nor would a board tolerate a CEO who does not stay abreast of current issues or assess a CEO without having set goals and objectives for the CEO to attain. Since the ultimate responsibility resides with the board, how can a board not apply the same standards to themselves that they apply to the management team they are overseeing (Lynch, 2004). 


\section{DUTIES OF A BOARD AS A COLLECTIVE GROUP}

Assessment of a board mandates a clear delineation of its duties. In reviewing the literature addressing the responsibilities of a governance board, I found a common distinction between the responsibilities of a board as a collective group and the responsibilities of an individual board member. This section of the paper reviews the responsibilities of the board as a collective group and the next section discusses the responsibilities of the individual board member.

Richard T. Ingram (2003) compiled a concise and clear list of board duties. Ingram points out that while “...there is no one-size fits all model to governance, there are fundamental responsibilities that hold true for almost every board” (Ingram, pg viii). Ingram's list includes:

1. Determine the Organization's Mission and Purpose.

Through the inclusion and consultation with the organizations members, staff, and other stakeholders, the board has the responsibility to adopt the Mission of the institution. This mission statement should drive the planning, budgeting, and rewarding of decisions within the organization.

2. Select the Chief Executive.

The board in consultation with appropriate stakeholders should make the final selection of the Chief Executive. In addition to selecting the CEO, the board should set the compensation package and be sure the position description, responsibilities, and expectations are clearly communicated to the new CEO.

3. Provide Proper Financial Oversight.

Based upon achieving the goals and objectives of the institution's mission, an annual budget needs to be developed, adopted, and communicated throughout the organization. While communication of the adopted budget is management's responsibilities, it is the board's responsibility to help develop and adopt the budget.

4. Ensure Adequate Resources.

Regardless of the nature of the non-profit, the board has the responsibility to ensure that adequate resources are available. For non-service entities, resources are obtained through contributions. For organizations that are service oriented, the board should ensure that adequate resources are available through the budgetary process. In this case the board members should take an active role by contributing to the organization and helping in the fund raising events to the extent possible.

5. Ensure Legal and Ethical Integrity and Maintain Accountability.

Recent organizations like Enron, Global Crossing, and Arthur Anderson have captured the headlines with their almost unbelievable frauds, embezzlements, or breach of public trust. One common element runs through the many negative headlines in recent years-- a lack of appropriate oversight. The outcome of this lack of oversight is the now infamous Sarbanes-Oxley Act, subsequently discussed in this paper. This oversight is the responsibility of the organization's board.

6. Ensure Effective Organizational Planning. Objectives and goals need to be established based upon the organization's mission. This long-range planning is often done through the strategic planning process. Although strategic planning can be conducted in a variety of manners, it is the board's responsibility to see that strategic planning is taking place and to take an active role in the process.

7. Recruit and Orient New Board Members and Assess Board Performance.

Excellent recruiting and orientation of new board members is the underpinning of the future strength of the board. In addition to good recruiting and orientation practices, a board needs to periodically assess its performance. This assessment should be done regarding the board in total every five to seven years and to individual board members at re-election time. Should board members feel another member's performance is not adequate prior to re-election; an intervening assessment should be performed to allow this individual the opportunity to improve on his or her performance.

8. Enhance the Organization's Public Standing.

Board members are not only visible to the members within the organization but also are ambassadors of the organization to the community at large. In this regard, board members have a responsibility to conduct themselves in the utmost professional manner. 
9. Determine, Monitor, and Strengthen the Organization's Programs and Services.

On at least a monthly basis, board members should receive quantitative and/or qualitative information to monitor the organization's performance. This monitoring should be consistent with the goals and objectives of the strategic planning process and, therefore, supportive of the organization's mission.

10. Support the Chief Executive and Assess His or Her Performance.

Board members should be supportive of the Chief Executive and his or her needs to achieve the performance initially indicated by the board upon the CEO's hiring. In addition, periodic assessment of the CEO's performance is also necessary. The board or a subcommittee of the full board should carry out this assessment.

\section{DUTIES OF THE INDIVIDUAL BOARD MEMBER}

Specific duties of individual board members evolve out of the collective board responsibilities listed above and may include:

- $\quad$ Gaining an understanding of the organizations mission, goals and objectives.

- $\quad$ Understanding the environment within which the organization operates.

- $\quad$ Preparing for meetings associated with the organization.

- $\quad$ Maintaining confidentiality with proprietary items of the organization or its members.

- $\quad$ Avoiding situations whereby special considerations are afforded a board member.

- Obtaining an understanding of the organizations financial statements in helping the board fulfill its fiduciary responsibility.

The aforementioned duties a board member assumes coupled with the Sarbanes-Oxley requirement that publicly traded companies have more financial experts on both audit committees and boards and more independent directors, has created a shortage of willing volunteers to fulfill these roles. According to Chrisman \& Co., a Los Angeles head-hunting firm, since Sarbanes-Oxley was enacted their business of finding qualified directors for boards has increased 30\% (Kuehner-Herbert, 2003).

\section{OTHER ASPECTS OF THE ASSESSMENT}

Fund Directions (2003) indicates that common criteria of a board self-assessment include aspects of attendance, involvement in discussions, ability to ask important questions and contributions to committees. Assessment of these types of inquiries are historical in nature since they are based upon past performance. However, there usefulness is futuristic as they position the board to make changes in a proactive attempt to face future challenges.

The methodology of collecting the data can easily be categorized between quantitative and qualitative. Quantitative data collection has the distinct advantage of being concise and concrete. The specific questions would be formulated and respondents would quantify their answer based upon the numeric scale being used. While this process lends itself to ease of summarizing data, qualitative questions provide a means for respondents to elaborate upon a specific issue. A hybrid methodology using a quantitative scale coupled with open ended questions and an instrument open to qualitative responses both encourages explanations and provides descriptive prose to the assessment.

One of the concluding issues a board must decide upon is what role will management of the organization play in the assessment process. Two main issues exist; should management input be sought regarding how the board is functioning and should management be apprised of the assessment results (Stuart, 2004). Having management input should serve as an invaluable tool for the board. If management feels there is some function or duty the board is not handling appropriately, the board can discuss the issue and concern and if deemed legitimate, address the concern. If management has issues with the board that the board feels is not within their scope of responsibility, then the board needs to instruct upper management to clarify the boards' role with the lower levels of management. In either event, not knowing the concerns of management, legitimate or not, would appear to let an unnecessary void continue within the corporate governance and communication system. 
Appendix A provides an assessment instrument used by the Superior Community Credit Union (SCCU).

This instrument was initiated by Bill Anderson (source unknown), Chairman of SCCU in 2005. The author of this article is the current Chairman of the Board for SCCU.

\section{REFERENCES}

1. Arens, A.A., Elder, R, J., \& Beasley, M.S. (2004). Overview of the Sarbanes-Oxley Act of 2002 with Other Changes in Auditing and the Public Accounting Profession, Upper Saddle River, New Jersey: Pearson Prentice Hall.

2. Begin, S. (2004). Nonprofits weigh new governance guidelines, Crain's Detroit Business, June 14, 2004 v20 i24 p. 26.

3. Cahill, J., (1994). Board of Directors: Duties and Responsibilities, Volunteer Achievement Program.

4. Cahill, J., (1994). Board and Management Policies, Volunteer Achievement Program.

5. Deloitte \& Touche LLP, Ernst \& Young LLP, KPMG LLP, \& Pricewaterhouse Coopers LLP. (2004). Perspectives on Internal Control Reporting, A Resource for Financial Market Participants.

6. Deloitte \& Touche LLP, Ernst \& Young LLP, KPMG LLP, \& PricewaterhouseCoopers LLP. (2004). Internal Control Over Financial Reporting, An Investor Resource.

7. Donaldson, W.H. (2003). SEC Chairman, Testimony Concerning Implementation of the Sarbanes Oxley Act before the Senate Committee on Banking, Housing and Urban Affairs, September 9.

8. Don’t Dismiss Sarbanes-Oxley, (2004). Credit Union Magazine, November 2004, p. 22.

9. How Boards Work, Pioneer Gets Ahead on Self-Assessment, (December 2003). www.funddirections.com, Volume 12, No. 12, Fund Directions.

10. Guerra, Jorge E. (2003). The Sarbanes-Oxley Act of 2002 and Evolution of the Corporate Governance Process, www.imaknowledge.org/sox, 12/1/03.

11. Hacker, Steven (2003). Does Your Board Measure Up? Association Management, January, p. 82.

12. Ingram, Richard T. (2003). Ten Basic Responsibilities of Nonprofit Boards, BoardSource.

13. Kuehner-Herbert, Katie (2003), Higher Board Standards A Boon for Headhunters, American Banker, August 6, 2003, v 168, i150, p. 5.

14. Lynch, Mark. (2004), Does Board Have Same Standard For Itself As Management? Credit Union Journal, December 6, 2004, v8, i140, p. 4.

15. McConnell, D. K., \& Banks, G. Y. (2003). How Sarbanes-Oxley Will Change the Audit Process, Journal of Accountancy, September, p. 49.

16. Prentice, Robert. (2005). Student Guide to the Sarbanes-Oxley Act, p. 24.

17. Ricchiute, David N. (2006). Auditing Thomson South-Western, p. 38-40.

18. Schnase, Lorna A. (2004). Ten Steps for Conducting a Fund Board Evaluation. The Investment Lawyer, December 2004, v11, i12, p. (3)7.

19. Spetzler, C., Arnold, A., Lang, J. (2005). Bringing Quality To Board Decisions, The Corporate Board, January/February.

20. Stuart, Anne. (2004), A Question of Questions, $D \& O$ Advisor, September 2004.

21. The Sarbanes-Oxley Act and Implications for Nonprofit Organizations, (2003). www.boardsource.org, www.IndependentSector.org, BoardSource and Independent Sector.

22. The Information That Boards Really Need, (2003). MIT Sloan Management Review, Spring, v44, p. 71 (6).

23. Weil, J. and Tannenbaum J., (2001). Big Companies Pay Audit Firms More for Other Services, The Wall Street Journal, April 10, p. C-1-C-2.

24. Weiner, S. (2003). Proposed Legislation: It's Impact on Not-for-Profit Board Governance, The CPA Journal Nov, v73, i11, p. 56 (3). 


\section{APPENDIX A}

\section{Superior Community Credit Union}

Board Self-Assessment Survey

Please rate your assessment of the Board of Directors' performance on a scale of 1- 5, with $1=$ Not At All Confident, and $5=$ Very Confident.

A. How Confident Are You That as an Effective Governing Body, the Board:

1. Monitors and evaluates the performance of the President/CEO on a regular basis? ( )

2. Ensures legal compliance with federal, state, and local regulations? ( )

3. Monitors financial performance and projections on a regular basis? ( )

4. Has a strategic vision for the organization? ( )

5. Has adopted an income strategy that combines earned income and other revenue to ensure adequate resources? ( )

6. Has a clear policy on the responsibilities of board members? ( )

7. Has adopted a conflict of interest policy that is discussed regularly? ( )

8. Currently contains an appropriate range of expertise and diversity to make it an effective governing body? ( )

9. Regularly assess its' own work? ( )

B. How Confident Are You That Most or All Board Members:

1. Understand the mission and purpose of the organization? ( )

2. Are adequately knowledgeable about the organization's programs? ( )

3. Act as ambassadors to the community on behalf of the organization and its members? ( )

4. Follow through on commitments they have made as board members? ( )

5. Understand the role that directors play in the organization? ( )

6. Understand the respective roles of the board and staff? ( )

7. Keep board proceedings confidential? ( )

8. Are appropriately involved? ( )

Please Comment On the Following:

1. What information about SCCU, or credit unions in general, would you like to get to help you be a better board member?

2. When you joined the board, did you have ideas on how you would help SCCU that haven't happened? If so, what ideas?

3. What suggestions/questions do you have for the board chair or executive committee about the board, your own role, or any other aspect of the organization?

4. Would you like the board chair or executive committee to contact you about getting together to discuss any item further? 